\title{
Nowe kooperatywne modele mieszkaniowe
}

\section{New cooperative housing models}

\section{Streszczenie}

Najważniejszy jest fakt, iż spoiwem tych przestrzeni są relacje międzyludzkie. Przegląd nowych modeli budownictwa mieszkaniowego - kooperatywnych działań różnych grup ludzi, których łączą wspólne marzenia o nowej jakości przestrzeni mieszkalnych, budowaniu nowych relacji i stanowienia części większego organizmu, odzyskaniu demokratycznego głosu w kształtowaniu przestrzeni miejskiej i działań proekologicznych.

Słowa kluczowe: budownictwo kooperatywne, nowe modele mieszkaniowe, budownictwo mieszkalne, szukanie alternatywnych kierunków

\section{Abstract}

The most important is the fact that the binder of these spaces are interpersonal relations. Review of new housing models - cooperative activities of various groups of people who share their common dreams about a new quality of living spaces, building new relationships and establishing a part of a larger organism, regaining a democratic voice in shaping urban space and pro-ecological activities.

Keywords: cooperative construction, new housing models, residential construction, looking for alternative directions 


\section{WSTĘP}

W mentalności przeciętnego Kowalskiego mieszkanie to konkretna przestrzeń o granicach wyznaczonych ścianami, miejsce będące własnym królestwem, moim i tylko moim, w którym jako król, mogę wszystko. Tok rozumowania podziela również sąsiad z prawej, który o porach rannych najeżdża królestwo zakłócając uświęconą ciszę a atak ten brzmi niczym wiertarka.

Widzimy tu przynajmniej dwa problemy społeczno-urbanistyczne (niedobrego sąsiada w tym przypadku pomijam, mimo iż faktycznie ten gad jest największym problemem). Niepokojąca diagnoza kondycji mieszkalnictwa w skali wsi, miasta, kraju i Europy². Zbiór stale zamkniętych i wydzielonych przestrzeni prywatnych, kompletny brak świadomej przynależności do większej grupy: społeczeństwa miasta, kolektywu mieszkańców czy sąsiadów. Przestrzeń dzieli się zerojedynkowo: MOJE albo NIE MOJE. Brak relacji i społecznych struktur pozwala na zaistnienie takim sytuacjom - nie liczymy się zbytnio z ludźmi, których nie znamy. To przecież tylko humanoidalny cień, interaktywna dekoracja windy. Wyliczamy dalej, kompleksy i uprzedzenia, mieszkania są niedostatecznie duże, a może nam się tylko tak wydaje? Może przestrzeń jest po prostu źle zaaranżowana? Ciągłe dążenie do pokazania swojej wyższości również sprzyja opisanej sytuacji. Kontakt z sąsiadami poza mieszkaniem jest krótki, lekkie skinienie głową i niewyraźny dzieńdobropodobny bełkot, ale to tylko element wojny, obserwujemy wroga na tym neutralnym terenie szukając słabych punktów, potem udamy się do szpiegów, siedzących na ławce przed klatką, siedzą tam od rana więc na pewno znają jakieś kompromitujące nowinki. Wyliczanie kończąc na miernej jakości budownictwa, gdyby ściana była dobrze wyizolowana to poranny remont sąsiada nie zakłóciłby snu.

Ta przerysowana sytuacja na szczęście nie jest normą, pokazuje jednak pewne tendencje i wady obecnego modelu zamieszkania, w Polsce dotyczy on znacznej ilości ludzi i potrzebuje zdecydowanych interwencji.

Problemy oczywiście na naszym kraju się nie kończą, sięgają daleko poza granice, przybierając różne formy i będące reakcją na różne przyczyny.

W 2008 roku w Hiszpanii dochodzi do pęknięcia bańki na rynku nieruchomości, centralnie sterowany rynek mieszkaniowy w ciągu krótkiego czasu spowodował znaczącą dysproporcję pomiędzy przeciętnymi zarobkami a cenami kupna czy wynajmu. Dopiero prywatyzacja większości rynku doprowadziła do złagodzenia sytuacji, która mimo to, pozostała bardzo napięta i wymagająca dalszych działań. Sytuacja uczy, iż w praktyce niemożliwy jest system polityczny, który uwzględnia potrzeby wspólnoty, istnieje ciągłe ryzyko przejęcia takowego przez element propagandowy albo chciwość pewnych grup ${ }^{3}$.

Niezadowalające warunki mieszkaniowe w Polsce i wielu miejscach Europy, wycofanie się państwa z procesu dostarczania mieszkań, narastające napięcia społeczne, starzenie się społeczeństwa i zrozumienie konieczności projektowania bardziej zrównoważonego spowodowały zrodzenie się kompletnie nowych modeli mieszkaniowych, ich tożsamą cechą jest silna i genetycznie zapisana wspólnotowość, współpraca a nie walka, dzielenie się 
przestrzenią a nie jej zagarnianie dla siebie, ochrona Ziemi zamiast jej nadużywania. Najważniejszy jest fakt, iż spoiwem tych przestrzeni są relacje międzyludzkie. W artykule przeanalizuję kilka scenariuszy, każdy prezentujący po części odmienny sposób wywiązania się ze stojących przed nimi wyzwań4. To właśnie te pionierskie odpowiedzi na problemy dotyczące większości miast i systemów postaram się przybliżyć i opisać ze szczególnym podkreśleniem możliwości i charakteru ich upowszechnienia. W małej skali, w pewnej awangardzie, rodzą się przyszłe masowe rozwiązania, zasady i style. Ważne jest ich możliwe najwcześniejsze wyłapanie i nazwanie. Traktuję przedstawione osiedla jako eksperymenty w drobnej skali będącej testem przed wyczekiwaną skalą globu. Kryterium wyboru obiektów stanowi chęć przybliżenia w artykule różnych, odmiennych „typów” takich osiedli, każdy wybrany obiekt charakteryzuje się zatem własną skalą, genezą powstania, odpowiedzią na najważniejszy problem, kierunkiem rozwoju. Są to przykłady pokazujące pewne skrajne rozgałęzienia na płaszczyźnie kooperatywnych modeli mieszkaniowych ${ }^{5}$.

\section{KOOPERATYW KRÓTKA HISTORIA}

Dotychczas w odniesieniu do omawianego modelu mieszkaniowego użyłem przymiotników i określeń takich jak „,nowe” czy „świeżo zrodzone”. Jest to jednak kwestia dystansu. Sama sytuacja połączenia w jedną grupę roli dewelopera, współprojektanta i odbiorcy ma miejsce już od początku ludzkiego osadnictwa, początki architektury, a później urbanistyki to przecież grupy ludzi zamieszkujących jaskinie, później miasta-wyspy, takie jak Jerycho. W mniejszej skali różne grupy cechowe czy wyznaniowe jak klasztory... itd. Dążono do pełnej własności jakiegoś miejsca, do wydzielenia go i oznaczenia, dlatego dom jednorodzinny jest bardziej pożądany od mieszkalnia w bloku, prywatność jest zachowana i zabezpieczona odpowiednim polem z każdej strony. To, co nowe i interesujące, to użycie takiego modelu jako recepty dla zwykłych ludzi, będący w ich odczuciu bardziej pożądanym miejscem niż ekspansywny tryb pełnej własności i ziemi niczyjej ${ }^{6}$.

\section{WROCŁAWSKIE KOOPERATYWY MIESZKANIOWE}

Polska z standardowym dla siebie opóźnieniem przyjmuje nowe trendy mieszkaniowe, kooperatywy tu dopiero powstają lub są bardzo świeże, widać jednak wiele pozytywnych reakcji, a ich udział ma się zwiększać.

Wrocław. Trzy budynki - dwa dla czterech rodzin, a jeden dla ośmiu. Architektura jest poprawna i upraszczając znaczenie tego słowa, można powiedzieć że nowoczesna. Jest to jeden z pierwszych projektów tego typu w Polsce. Na tle dokonań w Europie Środkowej nie wyróżnia się niczym poza jedną cechą - za całą inicjatywą stoją lokalni urzędnicy, którzy dla odmiany 
postanowili nie dokuczyć, a pomóc obywatelom. Zorganizowali działkę, wsparli logistykę i przekazali całość bezpiecznie w ręce dokładnie dobranej grupy życząc jej powodzenia. Dokonał się mały cud, albowiem udało się zakreślić linię na płaszczyźnie państwo-obywatele w idealnym miejscu, nie przeciągając jej zbytnie na niekorzyść zwykłych ludzi. Urząd poza pomysłem na taką realizację zajął się formalnościami i prawem pozostawiając jednak całą realizację mieszkańcom. To oni walczyli o kredyty, brali udział w projektowaniu i doglądali postępów w budowie. Jest to szczególnie ważne, ponieważ pierwszym i bardzo ciężkim krokiem dla kooperatywy mieszkaniowej jest robota papierkowa. Szczególnie uciążliwie przebiega ten proces w Polsce z jej nadmiarem biurokratycznych wymogów. Deweloper ma doświadczenie i wyspecjalizowanych w przepisach pracowników, kooperatywa z definicji robi to pierwszy więc pomoc ze strony urzędu jest zdecydowanie kluczowa i owocna. Wrocławska kooperatywa rodzi nadzieje, że takie projekty powtórzą się w innych częściach kraju i że uda się przy nich uzyskać pomoc instytucji czy urzędów.

\section{TRUDESLUND, KOPENHAGA, DANIA $-1981^{8}$}

Historia tej awangardowej kooperatywy zaczyna się pod koniec lat siedemdziesiątych, kiedy założyciele kupili atrakcyjny i bardzo kosztowny grunt na obrzeżach Kopenhagi, ich szalony pomysł spotkał się z otwartością i kreatywnością architektów a na styku tych płaszczyzn powstało wyjątkowe miejsce. 33 domy szeregowe ustawione wzdłuż L-kształtnej ulicy. W miejscu zgięcia ustawiono najważniejszy z budynków - dom wspólnoty, ten wyjątkowy obiekt stanowi w dużej mierze o niezwykłości tego miejsca. Jest to przestrzeń dla wszystkich mieszkańców nie akceptuje się od tej reguły żadnego wyjątku. Trzykondygnacyjny budynek służy jako miejsce spotkań, rekreacji, zabawy, posiada zaplecze kuchenne i jadalnię. Każda czynność, jaką można wykonać we własnym domu, może zostać wykonana również w Domu Wspólnoty. Posunięto się jeszcze dalej, wspólny 30- czy 40-osobowy obiad przygotowuje raz w miesiącu każda dwójka mieszkańców. Każdy z dorosłych ma obowiązek przynależeć do jednej z 16 grup, każda grupa dba o jakiś aspekt kooperatywy, z definicji przekształcając pracę w możliwość spędzenia przyjemnego czasu w gronie znanych sobie ludzi, robiąc przy okazji coś pożytecznego dla wszystkich.

Ostatnie dwa zdania pokazują dalekosiężność kooperatywności, jaką udało się osiągnąć w Trudeslund. Dodając do tego republikańsko demokratyczną strukturę zarządzania odśrodkowego i pewną otwartość oraz teoretyczną możliwość przyjęcia w szeregi osób z każdej grupy etniczno-poglądowej, dostajemy obraz idealnego miejsca, odpornego na problemy tego świata i skazanego na sukces. Krytycznym problemem jest tu kwestia skali, ten system działa tylko dla grupy o określonej liczebności do której przynależy się z własnej woli i ze świadomością jej istoty. Niemożliwe jest przeniesienie tego rozwiązania do większej skali, jedynie powtórzenie wielokrotnie tego rozwiązania. Jednostka podlega tu systemowi kontroli, dostaje i daje według ustalonego porządku, jest z tego rozliczana, oczywiście wszystko zamyka się w relacjach pomiędzy mieszkańcami, wszyscy biorą w tym udział albowiem chcieli, z myślą o tym wybrali 
mieszkanie w Trudeslund. Jednakże narzucenie takiego rozwiązania na już istniejącą grupę ludzi nigdy nie doprowadziłoby do powtórzenia się tego efektu. W końcu znajdą się przecież ludzie niechętni do współpracy, pojawią się problemy i wypaczenia o szerokiej skali, w gęstszej strukturze spotkałby się z kolejnymi problemami. Trudeslund jako możliwe rozwiązanie problemów wielu miast jest zatem nieodporne na różne społeczne i ekonomiczne skrzywienia. To wybitny przykład, jednak ciężko dopatrzeć się w nim szansy na „zbawienie” świata.

\section{COMMUNITY CAMPUS $87-2017^{9}$}

Ten świeży jeszcze projekt stanowi przełomowy etap istnienia trzydziestoletniej organizacji pomagającej młodym osobom skrajnie biednym czy bezdomnym. W najzwyklejszym budynku na północy Anglii 30 osób tworzy wspólnotę wspieraną przez osoby zapewniające wsparcie i pomoc. Powstanie obiektu Campus 87 poszerza zakres patrzenia na system mieszkalnictwa kooperatywnego, trzy lata temu grupa młodych ludzi związana z organizacją stała się współwykonawcą obiektu którego odbiorcami zostali później. Mimo iż owa grupa nie wystąpiła tu w roli dewelopera, to traktując instytucję społeczną, która odpowiada za pomoc tym ludziom oraz ich samych jako jedną kooperatywę jest to przykład pełnej samowystarczalności grupy ludzi w dążeniu do polepszenia swoich warunków bytowych. Kontrolując projekt na każdym etapie udało się uzyskać przestrzeń wysoce odpowiadającą na specyficzne potrzeby kooperatywy. Będąc osobami często bezrobotnymi mogli pomóc w realizacji tworząc własną przestrzeń życiową. Mimo pozytywnych odczuć i pewnego romantyzmu tej sytuacji łączenie roli dewelopera, wykonawcy i odbiorcy może nie być poszukiwanym rozwiązaniem. To świetny przykład rozwiązania problemu w małej skali jednak tak jak Trudeslund nie skaluje się do większej.

\section{WOHNPROJEKT WIEN - 2009 10}

Czterdzieści mieszkań mieści sto osób, które w 2009 postanowiły zrealizować marzenia o zrównoważonym, wolnym od uprzedzeń środowisku mieszkaniowym. Grupa uzyskała od początku silne wsparcie miasta, przez co ten duży projekt udało się szybko zrealizować w dogodnej lokacji blisko centrum Wiednia. Jak zawsze najważniejsza dla projektu była płaszczyzna styku pracy architektów i aktywistów-wizjonerów, przyszłych mieszkańców. W porównaniu do poprzednich, ten projekt mieści znaczną ilość osób na konkretnej przestrzeni, zatem oczywiste jest iż posługuje się nowymi środkami architektonicznymi i w pojęciu zespołu obiektów jako miastotwórczego miejsca - urbanistycznej. Zrównoważone, zdrowe i stypizowane rozwiązania budowlane tworzą środowisko dla relacji społecznych które musi istnieć zarówno na poziomie piętra, holu, kubatur wspólnych, otoczenia czy pomiędzy obiektami. 
Aspekt kooperatywny jest szeroko rozwinięty, wszyscy mieszkańcy biorą udział w debacie i zarządzaniu obiektem w sposób demokratyczny. Wszyscy podjęli się wykonywania prac dla wspólnoty w wymiarze kilkunastu godzin miesięcznie. Wohnprojekt w sposób niezwykle precyzyjny wyznacza relację przestrzeni prywatnej do wspólnej. Przestrzeń wspólna jest przeniesieniem wszystkiego czego oczekujemy od mieszkania do poziomu kooperatywnej własności, różne funkcje rozrywkowo-rekreacyjne i bytowe są dzielone, ale nigdy nie zostaje zakłócona prywatność, to co możliwe jest do zrobienia wspólnie przez fakt wykonania w grupie nabieraj nowej jakości, przykładowo zmywanie naczyń może być znacznie przyjemniejsze, gdy w trakcje możemy porozmawiać z kimś, kto w jakiejś mierze podzielę nasz światopogląd, przynajmniej w ujęciu na sposób mieszkania czy mieszkając samotnie albo przebywając samemu przez pewien czas, skorzystać z wspólnego salonu.

Ten podział jest warty podkreślenia. Wspólne miejsca są tak dobrane tak, aby fakt ich współwłasności wpływał pozytywnie na jakość ich funkcjonowania. Relacje pomiędzy mieszkańcami nie są wymuszone, życie w Wohnprojekt zgodnie z opiniami mieszkańców na lokalnym portalu jest niesamowitą przestrzenia do życia i wychowywania dzieci, wygląda ono niczym życie w wiosce, wyczuwalna jest wspólnota i korzyści z niej wynikające, jednak nie dochodzi do narzucenia się i przekroczenia linii prywatności. Projekt swoją skalą i rozwiązaniami zdaje się stanowić poszukiwań złoty środek i możliwy nowy kierunek dla rozwoju systemów budownictwa mieszkaniowego. Podkreśla to znaczna liczba wyróżnień i nagród, tj. PSH Europe - 2017.

\section{WNIOSKI I PODSUMOWANIE}

Ideową podwaliną dla systemu budownictwa kooperatywnego jest zauważenie że nikomu nie zależy na komforcie i jakości mieszkania tak bardzo jak samym mieszkańcom ani urzędnikom, ani prywatnym deweloperom. Traktując ludzi jako współwłaścicieli danego obiektu i jego otoczenia, sprawiamy, iż nabierają faktycznego poczucia odpowiedzialności i współzależności z otoczeniem. Trzeba przyjąć za oczywiste, że wszyscy dążą naturalnie do poprawy swoich warunków bytowych, więc działania podejmowane przez kooperatywę zawsze powinny wyznaczać najlepszy możliwy kierunek, podyktowany rzeczywistą skalą i bez interesów osób trzecich.

Podjęto walką z Goliatem, wspomniane inicjatywy znalazły nowe kierunki rozwoju, negując dotychczasowe systemy oparte na chęci zarobku, propagandzie poprzez ilość i bezdusznej masowości. Ludzie stojący za tymi zmianami chcą powrotu prawdziwej i dawno już utraconej demokracji w mieście, aby społeczeństwo mogło decydować o swojej przestrzeni, wyglądzie i charakterze miast. Celem jest przywrócenie równowagi i sprawiedliwości. Pewne projekty posuwają się dalej, tworzą całe wioski, grupy ludzi tworzących rodzinę i na płaszczyźnie społeczeństwa występujących jako jedność. Poprzez naprawę jakości mieszkań próbuje się też poprawić jakość Planety, osoby zaangażowane w takie projekty cechują się 
wysoko świadomością zmian w naturze, którym próbuje się zaradzić. W końcu Ziemia to nasz dom. Są inicjatywy dążące jedynie do finansowej czy logistycznej poprawy i niestawiające się $w$ alternatywie do istniejącego biznesu deweloperskiego. Produkcja własnej przestrzeni od podstaw, jej kontrola, łączą się chęcią naprawiania i zmienia świata na lepszy, podejmuje się próby wyciągania ludzi z biedy, walki z nietolerancją, przemocą i zagrożeniami współczesnego świata. Przestrzeń, architektura stają się wtedy punktem krytycznym i centralnym, tworzącym własną aurę, własny świat.

Każdy z wymienianych pomysłów posiada własną, często odmienną odpowiedź na dręczące pytania. Wszystkie jednak razem dają szerokie spektrum możliwości przed którymi stoją współcześnie miasta i społeczeństwo. Są to pewne poszukiwania w małej skali, na ich podstawie można jednak próbować odpowiadać na pytania o większej skalę, na przykładzie Polski jest to pytanie o pewien sposób czy zbiór cech dla grupowego budownictwa. Jak tworzyć miasta, dzielnice czy kwartały, w oparciu o jakie wartości, w jaki sposób. Jak łączyć dużą gęstość zabudowy z zrównoważoną, otwartą na ludzi, nadającą się do życia przestrzenią. Koniec końców, jak budować miasto żeby zachować w nim ludzką skalę?

Jest to paradoks, albowiem im większa jest gęstość miast na świecie, im bardziej w Chinach upycha się ludzi w monumentalnych betonowych dżunglach, tym silniej rośnie potrzeba indywidualności w kreowaniu własnej przestrzeni, odpowiedzialności za nią, szukania i budowania więzi. Modernizm dał lekcję że wielkie linijkowe miasta z betonu nie są odpowiedzią na problem tylko kolejnym problemem, kiedy zmierzamy w stronę zrównoważonego budownictwa coraz silniej daje się we znaki problem przeludniania i ciągnie nas z powrotem w spoisty i silnie zorganizowany układ. Te dwie płaszczyzny wymagają znalezienie złotego środka, szukają go od dawien dawna najlepsi, czy obserwując małe i niepozorne realizacje uda nam się do niego przybliżyć? 


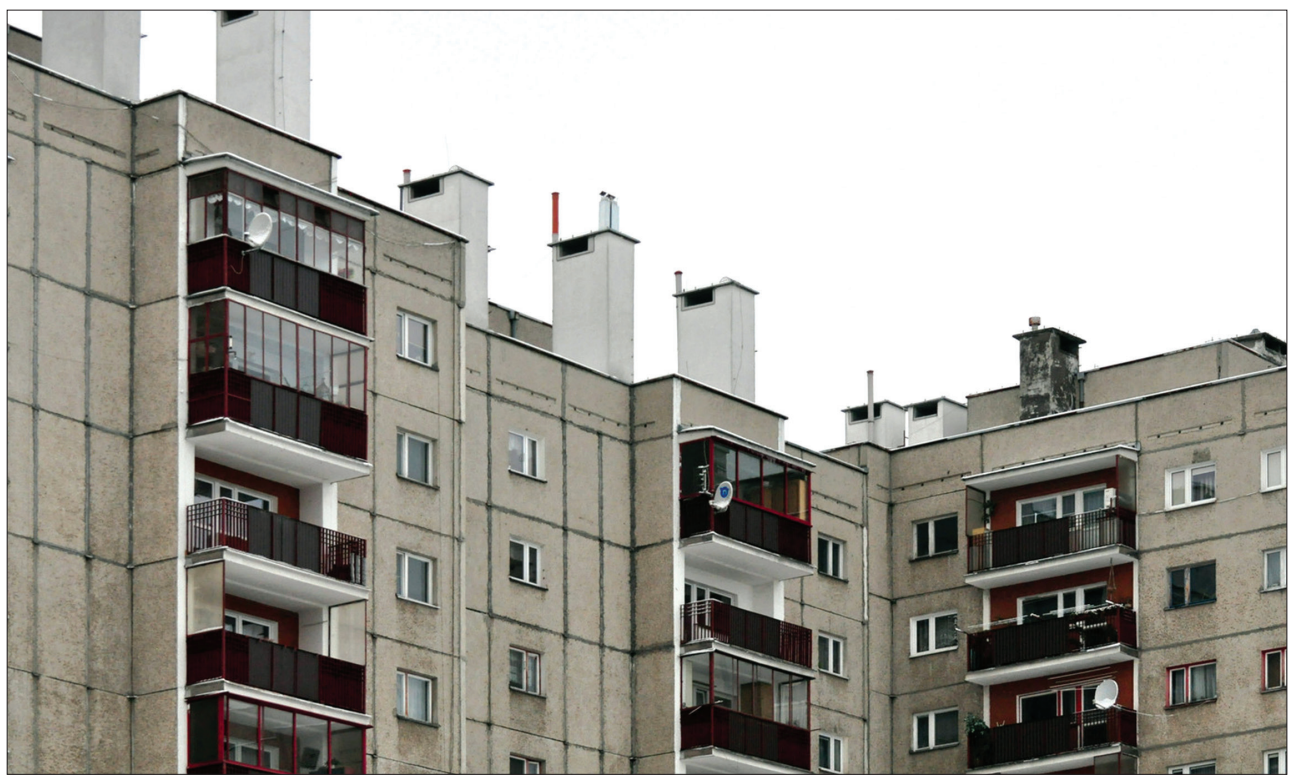

II. 1. Według szacunku, w roku 2013 w Polsce w budynkach z wielkiej płyty mieszkało 12 mln osób, a sama rewitalizacja w ocenie Izby Inżynierów Budownictwa kosztowałaby 200 mld zł (fot. A. Wiśniewski)

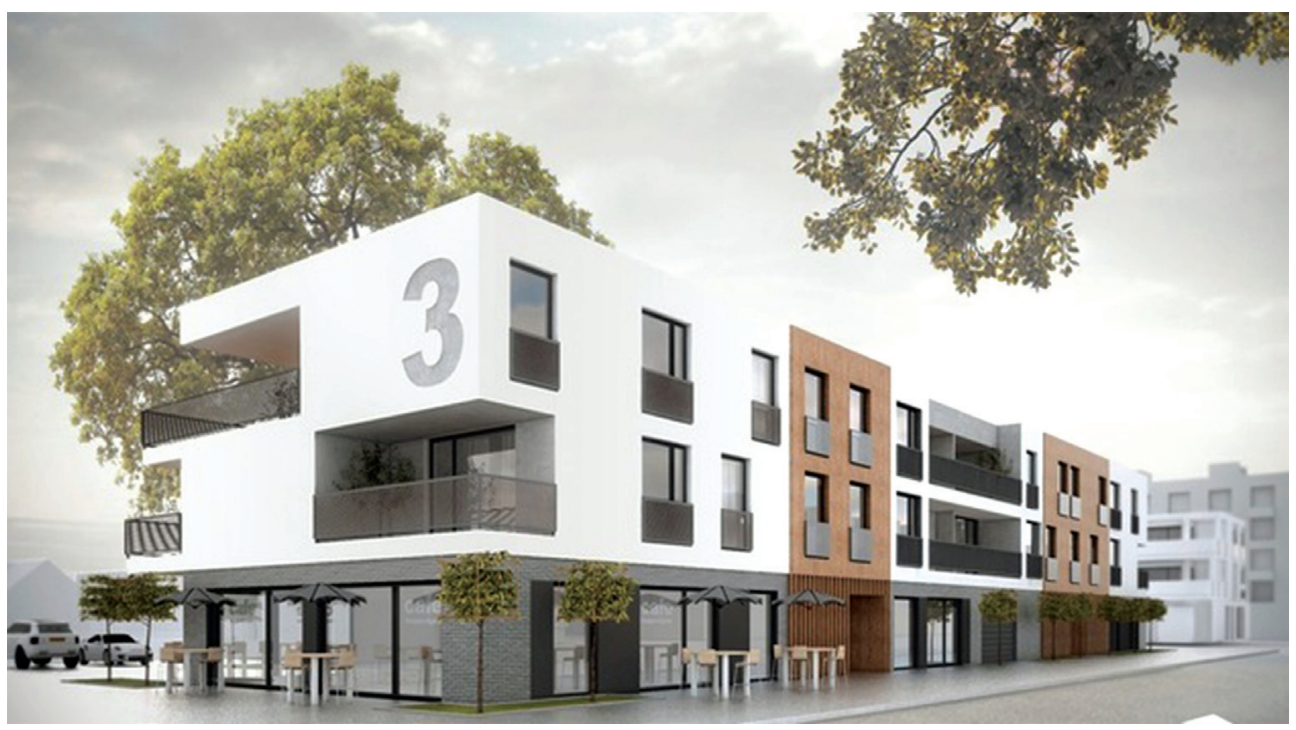

II. 2. Wizualizacja jednego z budynków tworzącego założenie

(źródło: zwycięzca konkursu, niepodany) 


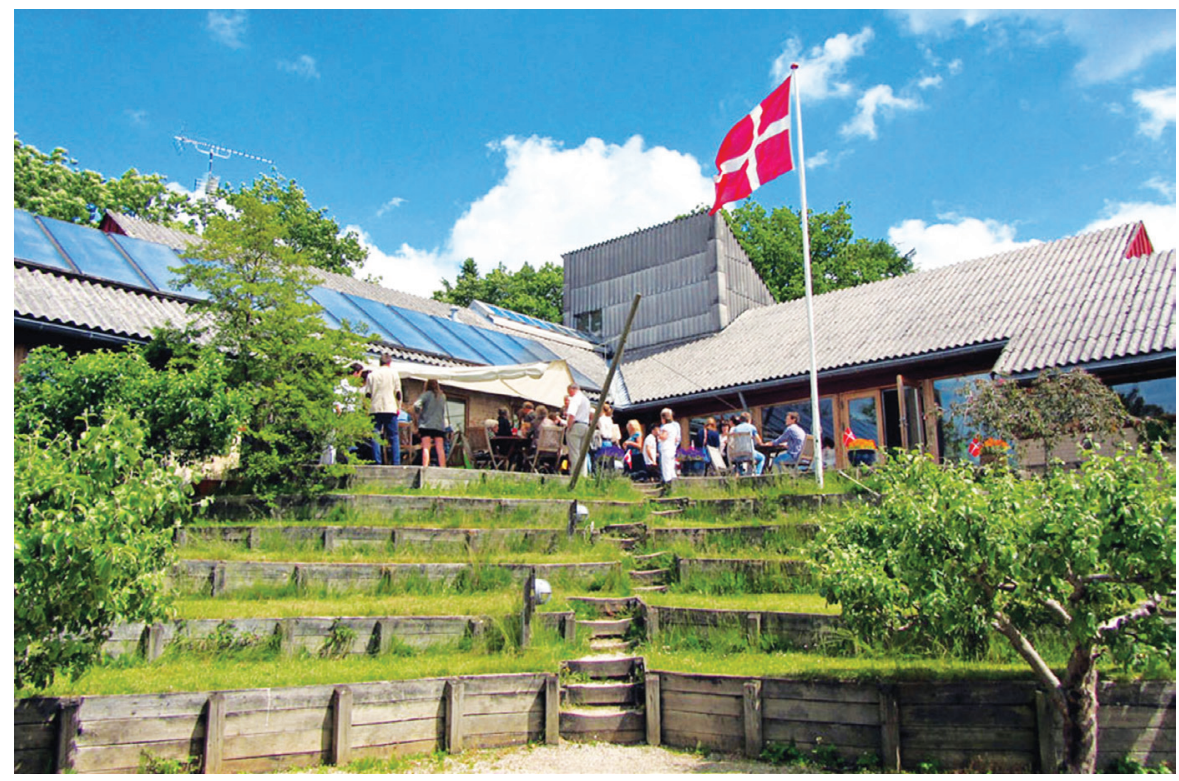

II. 3. Dom wspólnoty, usadowiony na nieznacznym wpienieniu tworzy wiele przestrzeni wokół siebie (źródło: własność merytoryczna portalu Urbamonde, udosętpniony)
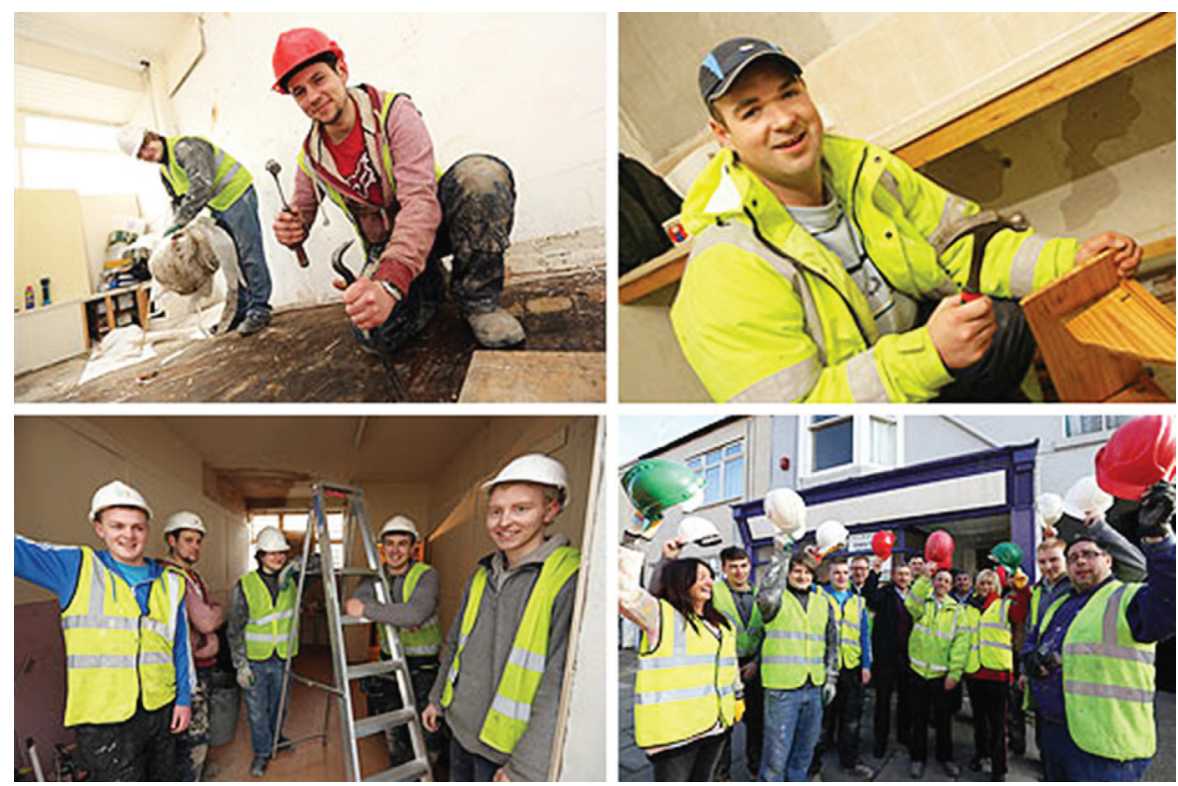

II. 4. Kolaż zdjęć z procesu wykańczania obiektu z pomocą podopiecznych instytucji (źródło: http://www.redcar- cleveland.gov.uk/rcbcweb.nsf/web+full+list/6aa223c72a383a78802577c 9004a090e; dostęp: 17.03.2018) 


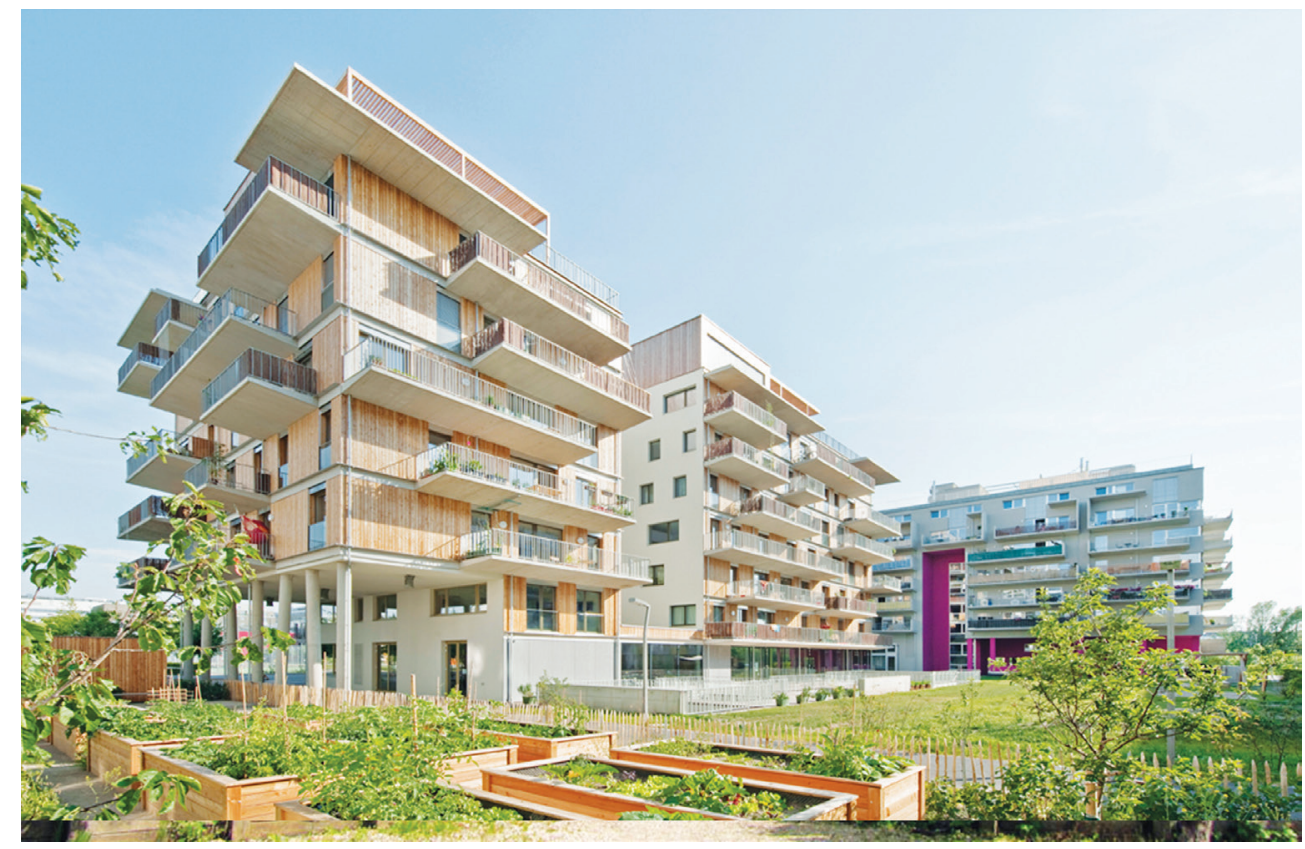

II. 5. Jeden z budynków tworzących założenie (źródło: Hertha Hurnaus) 


\section{PRZYPISY}

1 B. Varnai, Alternatywne modele własności w sektorze mieszkaniowym, „Autoportret”, 2017, 2, s. 75-79.

2 http://forsal.pl/artykuly/930468,jak-sie-rozpoczela-hiszpanska-katastrofa-mieszkaniowa. html (dostęp: 17.03.2018).

3 Wybór i przegląd projektów na przygotowałem na podstawie portalu https://psh.urbamonde.org/\#/pl/communities - najlepiej zorganizowany portal tego typu, na jaki natrafiłem, pierwsze spotkanie było przypadkowe, to ono było inspiracją dla napisania artykułu. Portal definiuje się następująco: „ten serwis to internetowy komponent inicjatywy Social Production of Habitat (Społecznego Budownictwa Mieszkaniowego), która promuje projekty oddolnego budownictwa mieszkaniowego z całego świata".

4 https://www.bankier.pl/wiadomosc/W-Polsce-brakuje-8-mln-lokali-aby-warunki-mieszkaniowe-staly-sie-europejskie-3166282.html (dostęp: 17.03.2018).

5 https://en.wikipedia.org/wiki/Housing_cooperative, http://www.housinginternational. coop (dostęp: 17.03.2018).

6 https://www.wroclaw.pl/kooperatywy, http://www.housinginternational.coop (dostęp: 17.03.2018).

7 https://cohousing-cultures.net/projects/trudeslund/trudeslund_featured_img/?lang=en, http://www.housinginternational.coop (dostęp: 17.03.2018).

8 https://www.facebook.com/CommunityCampus87, http://www.housinginternational.coop (dostęp: 17.03.2018).

9 http://wohnprojekt.wien, http://www.housinginternational.coop (dostęp: 17.03.2018). 


\section{BIBLIOGRAFIA}

Gehl J., Życie między budynkami, RAM, Warszawa 2009.

Graham W., Miasta wyśnione. Siedem wizji urbanistycznych, które kształtujq nasz świat, Karakter, 2016.

Jacobs J., Śmierć i życie wielkich miast Ameryki, CA Centrum Architektury, Warszawa 2014. Kajdanek K., Suburbanizacja po polsku, Nomos, 2012.

Kusińska E., Miasto przyszłości - zrównoważona dzielnica mieszkaniowa, Czasopismo Techniczne 3-A/2007, s. 163-170.

Le Corbusier, Kiedy katedry były białe, Fundacja Centrum Architektury, Warszawa 2014.

Montgomery C., Miasto szczęśliwe. Jak zmienić nasze życie, zmieniajq̨ nasze miasta, WZ, 2015. Springer F., Wanna z kolumnadq. Reportaże o polskiej przestrzeni, Karakter, 2016.

Sarzyński P., Wrzask w przestrzeni. Dlaczego w Polsce jest tak brzydko?, Polityka, 2013.

Varnai B., Alternatywne modele własności w sektorze mieszkaniowym, „Autoportret”, 2, 2017, s. 75-79.

Włoch-Szymla A., Kształtowanie się przestrzeni miejskiej w środowisku zamieszkania - Wiedeń, Czasopismo Techniczne, 3-A/2010, s. 301-310.

Wosińska W., Oblicza globalizacji, Smak Słowa, Sopot 2008.

CCH, http://www.cch.coop (dostęp: 17.03.2018).

International Co-operative, http://www.housinginternational.coop (dostęp: 17.03.2018).

Urbamonde, https://psh.urbamonde.org/\#/pl/communities (dostęp: 17.03.2018).

http://forsal.pl/artykuly/930468,jak-sie-rozpoczela-hiszpanska-katastrofa-mieszkaniowa.html (dostęp: 17.03.2018).

https://www.bankier.pl/wiadomosc/W-Polsce-brakuje-8-mln-lokali-aby-warunki-mieszkaniowe-staly-sie-europejskie-3166282.html (dostęp: 17.03.2018).

https://en.wikipedia.org/wiki/Housing_cooperative (dostęp: 17.03.2018).

https://www.wroclaw.pl/kooperatywy (dostęp: 17.03.2018).

https://cohousing-cultures.net/projects/trudeslund/trudeslund_featured_img/?lang=e (dostęp: 17.03.2018).

https://www.facebook.com/CommunityCampus87 (dostęp: 17.03.2018).

http://wohnprojekt.wien (dostęp: 17.03.2018).

ADRES BIBLIOGRAFICZNY ARTYKUtU: Ząbek P., Nowe kooperatywne modele mieszkaniowe, Przestrzeń/Urbanistyka/Architektura, $1 / 2018$, s. 57-68.

DATA AKCEPTACJI OSTATECZNEJ WERSII DO OPUBLIKOWANIA: 15.06.2018. 